that the same be properly arranged, classified, labeled, filed, calendared and indexed, all under the direction of the board of trustees of the state library and historical department.

(d) That for the care and permanent preservation by the curator of the historical department of the public archives herein before designated, the executive council is hereby authorized and directed to furnish and equip such room or rooms in the historical, memorial and art building as may be deemed necessary for the purpose of this act, and the room or rooms thus provided for shall be known as the division of public archives.

(e) Upon and after the receipt by the historical department into its division of public archives of any such public archives, copies thereof may be made, certified and authenticated by the curator in the same manner and with the same validity as the officer from whom the same were secured. The curator shall have and exercise the same custody and control over said public archives as had theretofore been exercised by those from whose offices they were received, but they shall not be removed from the historical depart. ment except by the consent of the curator and upon the subpoena of a court or the order in writing of the person from whose office they were originally derived. Said curator shall charge and collect for certified copies the same fees as are allowed by law to the secretary of state for certified copies which fees shall be turned into the state treasury, Such certificates signed by the curator shall have the same legal effect as like certificates issued by the secretary of state.

\title{
THE CARE AND USE OF DOCUMENTARY MATERIALS.
}

One of the valuable papers presented at the recent meeting of the American Historical Association at Chicago was that read by Mr. Lawrence J. Burpee, of the International Joint Commission, Ottawa, Canada, entitled "Restrictions on the Use of Historical Materials.". The discussion and. exhibits are particularly interesting to many here in Iowa immediately charged with the administration of Departments or Libraries containing extensive collections of public archives and documentary materials; for he presents not only the problems, perplexities and practices of the custodians of documents but he assembles the opinions and suggestions of numerous archivists and librarians.

Preservation, publicity and prudence seem to be the grand objectives and the grand perplexities. Shall the custodian 
stand guard over the precious document, armed to the teeth, alert with suspicious eye, presuming that the searcher after data will misuse or abuse, will damage or mutilate or steal that which he uses; or shall he be a Chesterfield and assume that every comer is a gentleman and presume him to be intelligent and honest and careful and give him the right of way without let or hindrance, indulging the belief that the greater number of users the greater the good? Principles and practice swing between these two extremes and always will. Philosophers and saints alike will be sorely perplexed to discover the golden mean whereon sense and sensibility coincide.

Mr. Burpee deals with sundry complexes of problems which librarians are constantly called upon to solve.

Are Departments or Libraries wherein archives and rare documents are found, to be regarded merely as depositaries for the sole use of the Government, or for the use of the general public? The better opinion or the weight of opinion seems to incline to the latter view.

Is preservation or publicity the major consideration? Preservation is a basic necessity and must be a paramount consideration, but much and almost perfect publicity may be attained or assured by means of publication and photographic reproduction. Freedom of access accorded general and special users and exemption from supervision and precautionary measures have often resulted in serious losses and abuses. These losses are not always due to the heedless or perverted layman with "unscientific" notions; but now and then they are chargeable to the misconduct of "historians" of reputation, of professors and "research" experts. Prudence enjoins greater or less restriction to prevent such losses or misuse.

Another sorry perplexity, alas! is that the faux pas and gaucheries of the honest, well-meaning, untutored and stupid are no less fatal than the perversions of the malevolent and unscrupulous-as many a bibliophile has discovered to his amazement and chagrin.

In the scores of responses to Mr. Burpee's questionaire we find a general agreement that the greatest freedom of 


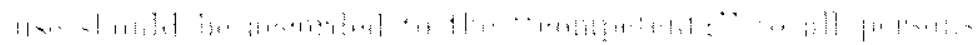
"1,

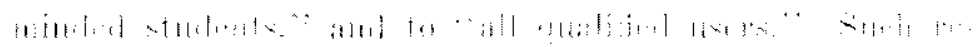

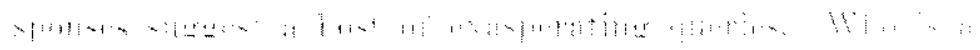

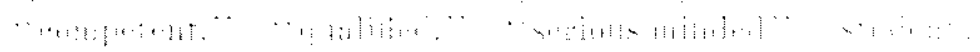

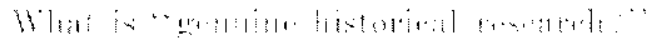

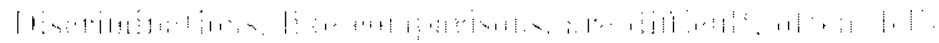

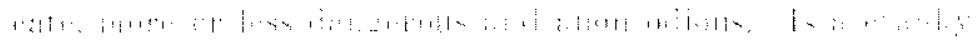

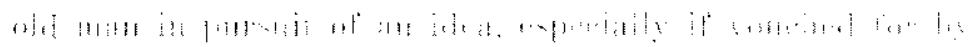

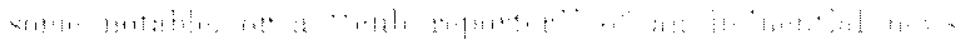

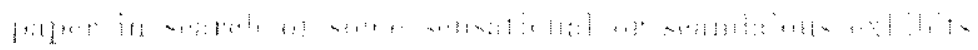

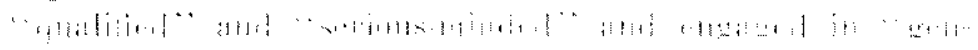

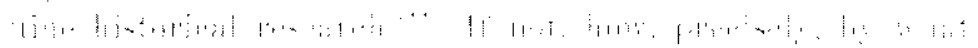

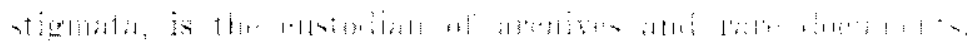

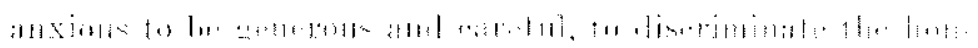

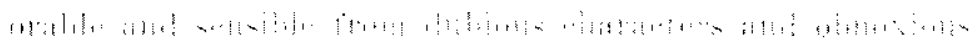

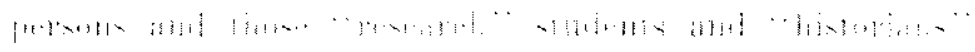

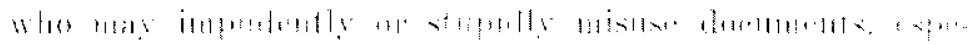

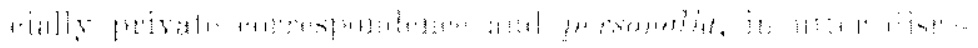

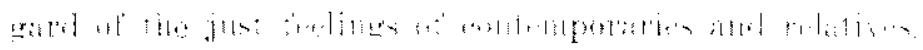

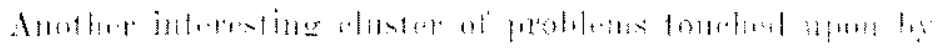

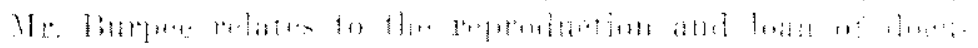

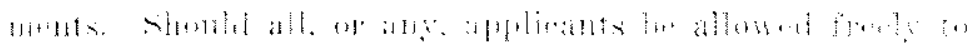

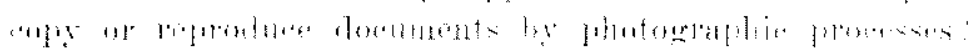

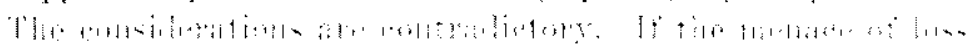

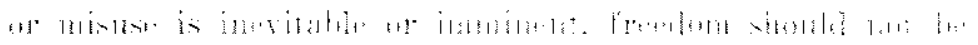

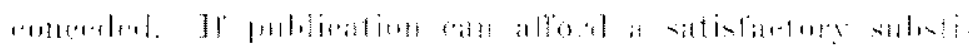

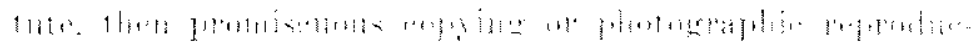

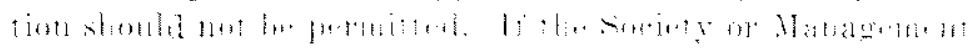

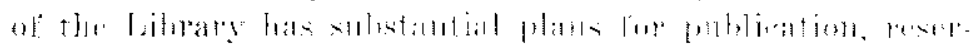

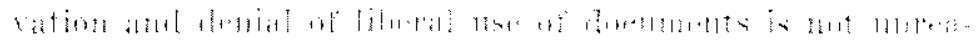

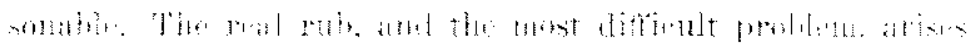

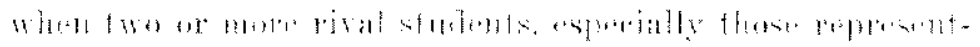

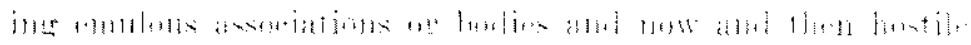

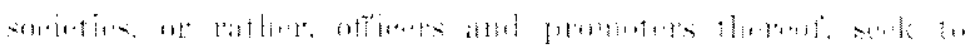

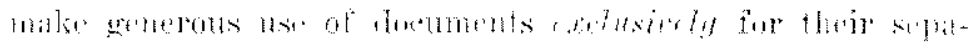

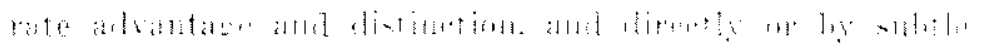

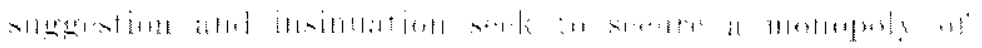

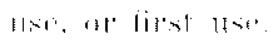




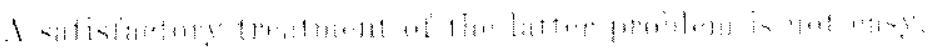

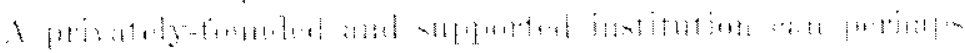
d a

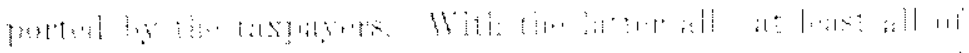

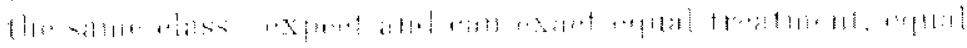

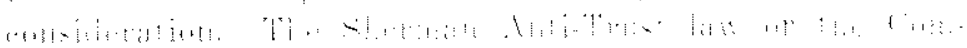

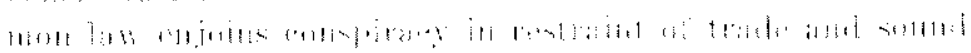
flalda ;

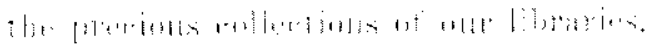

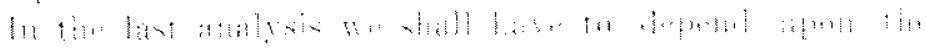

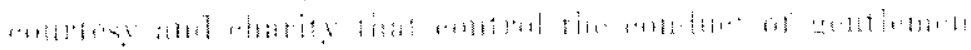

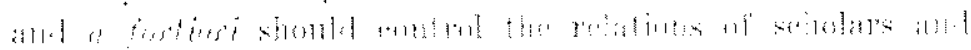

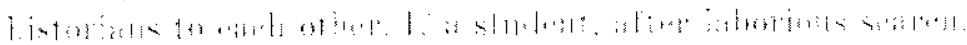

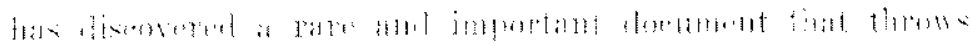

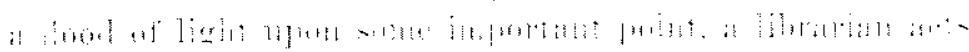

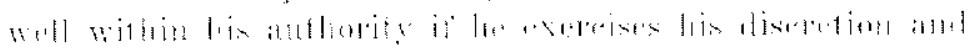

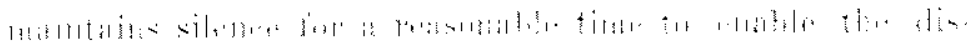

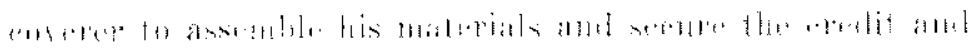

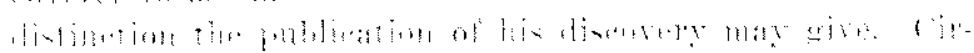

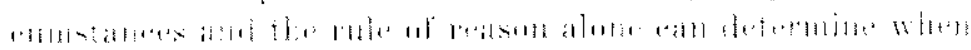

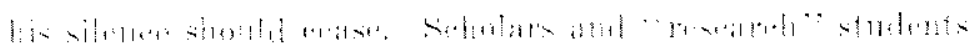

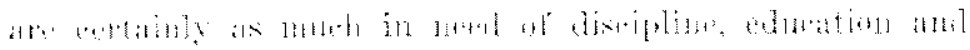

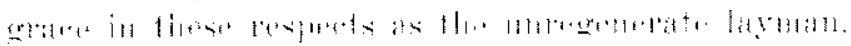

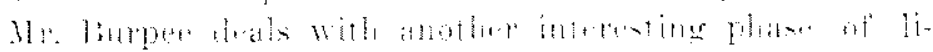

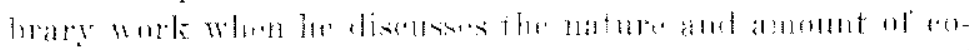

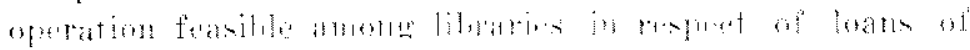

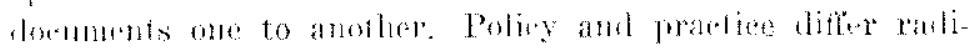

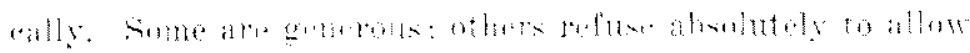

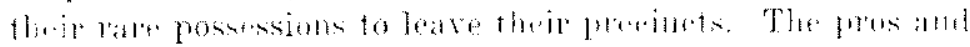

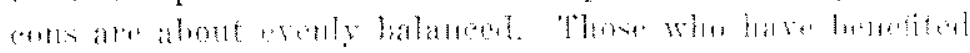

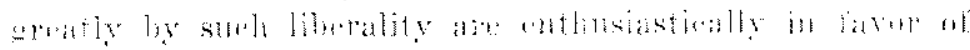

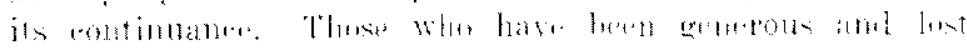

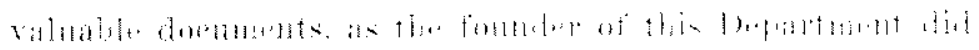

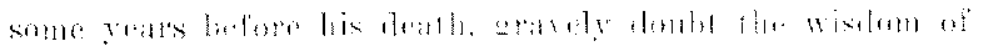

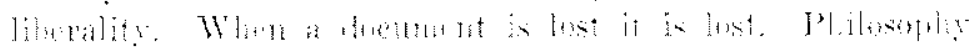

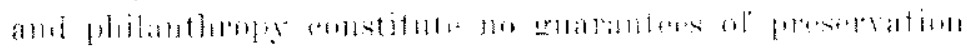

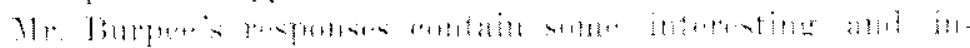

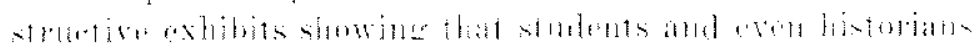

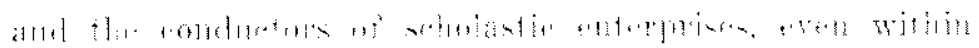


the sacred precincts of universities, are given to peculiar, not to say reprehensible practices in the use of documents obtained on loan.

The nature and degree of censorship and supervision actually enforced by librarians are interesting portions of Mr. Burpee's exhibits and discussion. Courtesy prompts to generosity and liberality; prudence and adverse experience prompt to close scrutiny and alert watchfulness on the part of the custodian. The degree of acquaintanceship between the custodian and the student or examiner for the most part seems to determine whether or not the examination is closely supervised by attendants. An analysis of human relationships must needs convince that this is the major premise of sensible procedure. The mechanical arrangements for supervision of those examining the collections in the Division of Manuseripts of the Library of Congress afford us an excellent illustration of a successful working scheme that "splits the difference" between the extreme policies advocated.

\section{USE OF OUR PUBLIC ARCHIVES.}

A survey of the written requests for the use of Iowa public archives which were required by the Curator of the Historical Department, shows that from June, 1914, to April, 1915, 133 requests for material have been taken care of. of these, eighty-one have come from the various State offices: fifty-eight from the Board of Health; three from the Governor; one each from the Secretary of State and Treasurer of State; seven from the Auditor of State; one from the Attorney General; three from the Executive Council; one from the Law Library; two from the Insurance Department; two from the Board of Education; one from the Railroad Commission and one from the Board of Control of State Institutions.

of the remaining inquiries, eighteen have been of a purely historical character, such as requests for information from persons making historical research with a view to publication of historical books, theses and articles for periodicals. Legal 
Copyright of Annals of Iowa is the property of State of Iowa, by \& through the State Historical Society of Iowa and its content may not be copied or emailed to multiple sites or posted to a listserv without the copyright holder's express written permission. However, users may print, download, or email articles for individual use. 